\title{
Ellipsis
}

Volume 44

Article 15

2017

\section{Dialogue in Jupiter}

M. M. Kaufman

Follow this and additional works at: https://scholarworks.uno.edu/ellipsis

\section{Recommended Citation}

Kaufman, M. M. (2017) "Dialogue in Jupiter," Ellipsis: Vol. 44 , Article 15.

DOI: https://doi.org/10.46428/ejail.44.15

Available at: https://scholarworks.uno.edu/ellipsis/vol44/iss1/15

This Poetry is brought to you for free and open access by the Department of English and Foreign Languages at ScholarWorks@UNO. It has been accepted for inclusion in Ellipsis by an authorized editor of ScholarWorks@UNO.

For more information, please contact scholarworks@uno.edu. 


\section{Dialogue in Jupiter}

M. M. Kaufman

Vassar Miller Poetry Award Honorable Mention

Times when the moons of Jupiter disappear behind - "That swollen planet?"

-when you think you've lost something, the spaces between eclipses reveal-

"Disappear behind that swollen planet, the one you call your mother."

The spaces between eclipses reveal, uh, see, the speed of light. "Bears it:

The one you call your mother, she loves you like anyone does a sea." The speed of light bears it"Nothing-more than. Relative, see?

She loves you like anyone." Does a light cross at once? Or is it nothing more than relativity? Times of year when Earth-

"A light cross is won. Or is it, heavy and slow? A turtle with a burden?"

Times of year when Earth draws towards Jupiter's orbit_- "Breath:

heavy and slow. A turtle with a burden, your mother lays down her planet for a minute, two. Draws, too: Words, Jupiter's orbit, breath." Earth moves away, eclipses appear earlier-

"Your mother lays down her planet for a minute to wonder at its modern value. Why carry it?" Earth moves away, eclipses appear early. Or could it be the other way? Motherfu- "For once go and

wonder at your modern value. Why carry it any further? You've gone over the edge." Could it be the other way, Mother? For once- "Go and realize you're on the wrong planet." 
Any further-you've gone over the edge. Times when the moons of Jupiter"Realize you're on the wrong planet!" when you think you've lost something- 